


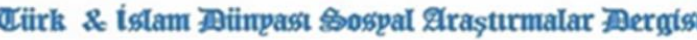

The Journal of Turk \& tstam Morlo Sotal Stưtes

\title{
Türklerde Demir, Demirci ve Anadolu'da Sıcak Demirciliğin Problemleri
}

\section{Iron, Blacksmith in Turks and Problems of Hot Blacksmithing in Anatolia}

\section{Murat ÇETIN*}



Geliş/Submitted:

06.11 .2021

Kabul/Accepted:

24.12.2021

Yayın/Published:

Citation / Atıf

Çetin, M. (2021). Türklerde Demir, Demirci ve Anadolu'da Sıcak Demirciliğin Problemleri. Türk \& İslam Dünyası Sosyal Araştırmalar Dergisi, 8 (31), 214-225.

Çetin, M. (2021). Iron, Blacksmith in Turks and Problems of Hot Blacksmithing in Anatolia. The Journal of Turk \& Islam World Social Studies, 8 (31), 214-225.

Makale Türü:

Araştırma Makalesi
Article Information:

\section{Research Article}

\subsection{8/TIDSAD.54875}

This article was checked by Intihal.net. Bu makale İntihal.net tarafından taranmıştır.

This article is under the Creative Commons license. Bu makale Creative Commons lisansı altındadır.

*Prof. Dr. Erzincan Binali Yıldırım Üniversitesi, mcetin@erzincan.edu.tr 



\author{
Türklerde Demir, Demirci ve Anadolu'da Sıcak Demirciliğin \\ Problemleri ${ }^{1}$
}

Iron, Blacksmith in Turks and Problems of Hot Blacksmithing in Anatolia

\title{
Prof. Dr. Murat ÇETIN
}

Öz: Mitolojiye göre, Göktürklerin ataları demircidir. Türkler için demir kutsaldır ve demircilik, en saygın meslek dallarının başında gelmektedir. Ergenekon Destan'ında yer alan kurtarıcı demirci motifinin kökleri oldukça eski çağlara dayanır. Türklerin zihinsel algısında "Gökyüzü Tanrısı" anlayışının merkezinde bulunan demir, Tanrı'nın özüdür. Tarih boyunca demir, insanların korunma, savunma ve barınma gibi doğal ihtiyaçlarını karşılamak için değerli bir elementtir. Türkler tarafından, demirin silah ve diğer aletler yapılmasında kullanılmasının yanında, hastaları iyileştirmek, doğal olaylara cevap vermek, insanları kötü ruhlara ve kötülüğe karşı korumak gibi sembolik özelliklere sahip olduğuna inanılmaktadır. Demirle ilgili her şey toplumların hafızalarda canlıdır ve demirciler de toplumların ortak kültürel değerleri hakkındaki algı ve tasarımlarını taşıyan kişiliklerdir. Yarım asır önce şehirlerimizde, geçmişte her köşe başında rastlanan demirci atölyeleri, son yıllarda büyük oranda azalmıştır. Günümüzde iletişim hızının etkisiyle, özellikle ürün pazarlama ve ticarette küresel dünya kare bir dünyaya dönüşmüştür. Bu dönüşümle birlikte teknolojik araçların ve seri üretim tekniklerinin kullanımı sonucunda soğuk demircilik gelişmiş fakat tarıma dayalı sıcak demircilik önemini kaybetmiştir. Bu değişimlerin sonucunda, sıcak demircilik sektöründe faaliyet gösteren ustaların çoğu meslek hayatını sonlandırmış ve bazıları endüstriyel kalkınmanın etkisiyle sektör değiştirmiştir. Bu çalışmada, Türklerde kutsal değeri olan sıcak demircilik ve Anadolu'daki günümüz demirciliğinin sorunları ve çözüm önerileri sunulmuştur.

Anahtar Kelimeler: Mitoloji, Ergenekon, demir, demirci, Anadolu demirciliği.

Abstract: According to mythology, the ancestors of the Göktürks were blacksmiths. For Turks, iron is sacred and blacksmithing is one of the most respected professions. The roots of the savior blacksmith motif in the Ergenekon Epic go back to ancient times. Iron, which is at the center of the understanding of "God of the Sky" in the mental perception of the Turks, is the essence of God.

1 “COPE-Dergi Editörleri İçin Davranış Kuralları ve En İyi Uygulama İlkeleri” beyanları: Bu çalışma için herhangi bir çıkar çatışması bildirilmemiştir. Bu çalışma için etik kurul onayı gerekmemektedir.

Statements of "COPE-Code of Conduct and Best Practices Guidelines for Journal Editors": No conflicts of interest were reported for this article. Ethics committee approval is not required for this article. 
Throughout history, iron has been a valuable element for meeting people's natural needs such as protection, defense and shelter. By the Turks, In addition to being used in making weapons and other tools, iron is believed to have symbolic properties such as healing the sick, responding to natural phenomena, protecting people against evil spirits and evil. Everything about iron is alive in societies' memories, and blacksmiths are personalities who carry their perceptions and designs about the common cultural values of societies. Half a century ago, blacksmith workshops, which were found on every corner in the past, have decreased significantly in recent years. Today, with the effect of the speed of communication, the global world has turned into a square world especially in product marketing and trade. With this transformation, cold blacksmithing developed as a result of the use of technological tools and mass production techniques, but agricultural hot blacksmithing lost its importance. As a result of these changes, most of the masters operating in the hot forging sector have ended their career and some of them have changed the sector with the effect of industrial development. In this study, hot blacksmithing, which has a sacred value in Turks, and the problems and solutions of today's blacksmithing in Anatolia are presented.

Keywords: Mythology, Ergenekon, iron, blacksmith, Anatolian blacksmithing.

\section{Giriş}

Türk tarihinde ve kültüründe ekonomik uğraş olmanın çok üstünde bir yere sahip olan demircilik, pusat yapımının temelini oluşturduğu için Türkler ile özdeşleşen en temel el sanatıdır. Demiri ilk kez işleyip ona şekil vererek, Demir Çağı'nı başlatan Türkler demirden yapılan silahlar ile cihana hâkimiyet kurduklarından demire olağanüstü değer atfetmişlerdir. Bozkır Türk kültürünü meydana getiren üç temel öge at, koyun ve demirdir. Demirin kolay bulunması ve sağlamlığı Bozkır kültürü için vazgeçilmez bir metal olmasında önemli bir etken olmuştur (Koçak, 2016: 77-82, Kafesoğlu, 1977: 35, 55). Türkler, bozkırın zorlu şartlarına uygun malzeme olarak önceleri bakır ve bronz işlemişler, daha sonra geniş çapta demir metalini kullanmışlardır. Demircilik için fevkalade elverişli bir zemine sahip Asya bozkırında demir cevherlerinin yerleri tespit etmiş ve cevheri işleyerek demiri üretmişlerdir. Türkler; kılıç, kama, hançer, ok uçları, balta, mızrak başı, kalkan, topuz ve zırh gibi silah yapımında demiri özellikle kullanarak diğer yaşayan topluluklara üstünlük sağlamışlardır. Ayrıca tarım üretiminde ve gündelik hayatın içinde demirden yapılmış birçok alet ve ürünler kullanılmıştır. Türk kültüründe çok erken çağlarda atın daha rahat yönetilmesi için yapılan üzengi ve gem yapımında da demiri kullanmışlardır (Koçak, 2016: 10). Zengin cevher yataklarının Ural Altay dağları bölgesinde olması Kazakistan'da demir çağının başlamasında etkili olmuş, demircilik mesleği ile savaşçlık iç içe geçmiştir (Ögel, 1991: 38). Demir farklı kültür coğrafyalarında bilinmesine rağmen, gerçek demir çağı bu madenden bol miktarda alet ve silah yapımıyla başlamıştır. Altaylılar, mahir demirciler olarak bilinmektedir ve silah yapımında kullanılan demir madeni Yenisey nehrinin kaynak bölgelerinde büyük ölçüde bulunmaktadır. Çin kaynaklarına göre, Yenisey'in yukarı yatağı dolaylarında ve Tuba ırmağı boyunca demir cevheri bulunmaktadır. Yüksek kalitede demir cevherine sahip Kuzey Altaylarda yapılan kazı çalışmalarında demir eritme ocakları bulunmuş, Baykal'ın doğusunda demir ocak ve döküm yerleri ortaya çıkarılmıştır. İnsanlık tarihinde demir çağına başlangıç oluşturacak miktarda demir madeninin varlığı demir 
çağının eski Türk yurdunda başladığı düşüncesini desteklemektedir (Kafesoğlu, 1989: 210-211). Demir, Türk kültür çevresinde daha da fazla önem taşır hale gelmiş, Türklerin sosyal, siyasi, iktisadi, askeri ve dini hayatı ile sanat anlayışında birinci derecede yer edinen bir maden olmuştur. Bu durum demirin Türk kültürüne kazandırdığı kararlılığı ve gücü göstermektedir (Durmuş, 2017: 61). Türeyiş Destanlarından, Reşideddin Fazlullah'ın Cami'üt-Tevarih adlı eserlerinde demirin eritilmesi yer almaktadır. Demir madeni eritme; bir sınav, zorluk, zekânın zorlukların üstesinden gelmesi ve önüne çıkan engelleri aşmayı ifade ederken, demir ise Türeyiş destanlarının temelini oluşturan önemli bir kültürel değer olarak tanımlanmaktadır. Demir, gücü temsil eden bir araç, savaşta kullanılan en önemli malzeme ve silah sanayisinin simgesi olan metaldir. Kutsal bir zanaat olarak demircilik, hayvancılıkla geçimini sağlayan bozkırlı Türklerin en önemli ve hayatı uğraş alanlarından bir tanesidir. Bozkır Türklerinin savaş sanatlarında çok önemli bir yeri olan demir, savaşlarda üstünlüğü sağlayan kılıç, kalkan, kargı, mızrak, temren gibi savaş aletlerinin yapıldığı önemli bir madendir (Kafesoğlu, 1977: 193). Türklerde ordunun önemi, vatan ve milleti koruyacak gücün silaha sahip asker/ordu olduğu "demirci" ile temsil edilmekte ve doğuştan asker bir kavim için demir dağları eriten destana sahip olmak büyük önem taşımaktadır (Bastem, 2019: 233). Demircinin mesleki hünerleri eserler olan zırh, kalkanlarla, büyük zaferler kazanmalarını sağlayan, aynı zamanda ölümlerine de neden olan silahların üretildiği demircilik ile savaşçlık da iç içe geçmiştir (Ögel, 1991: 66). Demir yüzyıllar öncesinde Türkler için ekonomik açıdan çok önemli bir gelir kaynağı olmuş, Türkler, Çin'den Roma'ya kadar uzanan geniş ve büyük bir coğrafyada demir ticareti yapmış, vergilerini demir ile ödemiş, demir ile tahsil etmiştir. Demir, eski Türk dinini de etkilemiş, dini törenlerin ve törelerin vazgeçilmez bir unsuru olmuştur. Türkler demir (kılıç) üzerine ant içmiş, yeminlerinde üst bir kuvvet olarak onu şahit tutmuşlardır. Kutsal değeri ve teknik özellikleri sebebiyle demir, Türk'ün birey ve toplum hayatında, isimlerinde, unvanlarında, atasözleri ve deyimlerinde en çok kullanılan unsurların başında yer almaktadır (Yağcl, 2015: 5).

Zengin bir mitolojiye sahip olan eski Türklerde, demircilik kutsal bir el sanatı olarak çok önemli değerler manzumesini ve bilgilerini içermektedir. Göktürklerin ve Oğuzların dedeleri demirci olduğundan, bu inanca göre dokuz atası demirci olan bir kimse kam/şaman olabilme yeterliliğine sahip ve kutlu kişidir (Ziya Gökalp, 1991: 268). Türk töresinde demirciler ve şamanlar aynı soydan sayılan kutlu kişilerdir. Çinlilerin Tsu-k'ü adını verdiği Hun boyları 4. yy'da Budizmi benimsemişler, Gansu-Kansu ve Turfan içinde Buddha dinine bağlı kağanlar tarafından idare edilen devlet kurmuşlardır. Budist Tsü-k'ü devleti Çin saldırılarına karşı Kansu'da yaşayan Türkleri savunamamış, Turfan ve Kansu'da yenilgilerin sonucunda Altay'a göç etmişlerdir (Taşağıll, 2003: 53). Ergenekon Destanı, Türklerin uzun yıllar Ergenekon adını verdikleri bir dağda güvenli bir şekilde yaşadıkları, çoğalıp güçlendikten sonra demir dağı eriterek Ergenekon çıkıp ata yurduna geri dönüşlerini anlatır. Ebü'l-Gâzî Bahadır Han'a göre, türeyiş destanında Türkler, Ergenekon dağında bir demir damarına deriden yapılmış ve 70 ayrı yere yerleștirilmiş 70 büyük körük ile ateş yakarak demirden dağı eritip, kendilerine bir yol açmışlar ve bir bozkurt tarafından yol göstermesi ile Ergenekon'dan çıkmışlardır. Türkleri Ergenekon'dan kurtaran bir demircidir ve Göktürklerin atalarının etrafı dağlarla çevrili Ergenekon'dan çıkışlarının bir dağda bulunan demir madenini ateşle eriterek gerçekleştiğinden demircilik mes- 
leğinde ne derece ileri olduklarını gösterir (Ögel, 1991: 70). Yakut Türklerinde de demircilik gerek din ve gerekse bir sanat olarak büyük bir önem taşır. Yakut Şamanı "Yakut ulusuna, kudretli demirciler göndererek lütufta bulunan Kıtay Baksı Toyon'a saygı göstereceğim “diye dua etmektedir. Yakutlara göre; Kıtay Baksı Toyon, demircilerin koruyucusu" olan bir ruh ve yeraltında yaşayan "Sekiz Yeraltı Tanrıları"nın soyundan gelmektedir. Yakutlar en büyük demircilerin Ağlıs adı ile tanımlar ve Yakut lehçesinde Ağl, "kutsal koruyucu ve muhafız" anlamına gelmektedir. Yakut Türklerine göre "aile ocağı" sönmemesi gereken "Kutsal bir ateş" idi, bu ocağı koruyan bir ruh vardır ve ocakta yanan meșe (Mas) ağacı da kutsal bir ağaç olarak tanımlanmaktadır. Türk töresinde, demircinin çekiç, örs, kıskaç ve körük gibi önemli demirci alet ve edevatları kutsal sayılırdı. Türk mitolojisine göre bunların her birini de ayrı ayrı koruyan, "Koruyucu melekleri ve ruhları" vardı. Yakutlar bu ruhlara "Efendi, sahip" adlarını verirlerdi. Yakutlar, Ruslarla olan ilişkilerinden sonra, onlardan demircilikle ilgili birçok aletler almış olmalarına rağmen bu yeni ve yabancı aletlere kutsal bir önem vermemişlerdir. Kutsal demirci aletlerinin hepsi yerli ve eski biçimde yapılan aletlerdir ve bu çok önemli bir hassasiyettir. Demirin kötü ruhları kovduğuna inanıldığından dolayı ölmüş insanların cesetlerinin üzerine demirden yapılmış kılıç veya demir bir eşya konulurdu. Demircilik, Türklerin kutsal mesleği olduğundan dolayı kılıç ve bıçağın kutsal sayılması demirden olmasıdır. Demire şekil veren demirciler, toplum içerisinde son derece saygın bir konuma sahiptiler (Ögel, 1991: 68). Manas Destanında, Manas'ın her akın öncesi demircisine kılıçlarını bilettiği, silâhlarını tamir ettirdiği ve yola çıktığı anlatılmaktadır. Manas, demircisini hükümdar tarafından verilmiş çok yüksek bir üstünlük unvanı olan Tarkan saygı ifadesi ile çağırırdı. Tarkan'lar vergi vermezler, ceza görmezler ve bu rütbeleri nesilden nesile devam ederdi. Demir ruhu ve demirci insanlara kötülük getiren Albastı ruhunun da en büyük düşmanı olarak kabul edilmektedir. Kazaklar, loğusa kadınları Albastının kötü ruhlarından korumak için, ellerine bir demir parçası veya bir çekiç alarak “Demirci geldi! Demirci geldi!” diye bağırırlar ve Albastının demirciden korktuğu için loğusanın yanına yanaşmadığına inanırlar (İnan, 1986: 84, Ögel, 1991: 69). Orta Asya'da Türklerle yakın etkileşimde olan Buryatlara göre Türk demirciler devamlı ateşle beraber olduğu ve ateşle çalışmasından dolayı bir sihirbazdır. Buryatlar, "taşı alıp, eritip, demir yapan demirci, hem akıllı ve hem de korkunç bir kişidir" ve "tabiatın birçok karanlık sırlarını" da bilir. Rus etnograf D. Klements, Buryatların demircilik ve demirle ilgili olan inanışların Buryatlara dışarıdan geldiğini ve Buryat efsanelerinin "demirciliği bir zamanlar göçüp giden yabancı bir kavimden öğrendiklerini" ifade etmektedir. Demirciliğin merkezinin Yenisey ve Güney Batı Altayların Göktürk bölgeleri olduğu kuvvetle muhtemeldir (Ögel, 1991: 69).

Türk mitolojisinde ateş; ocak, yuva, halk anlamlarını da iafde eden kültürel bir kod olarak özel bir yere sahiptir. Mitlere göre "Demirciler, özel ruhlarca korunurlar, ateşi bulan, insanlara tarımı, hayvanları evcilleştirmeyi öğretendir. Demirci, aynı zamanda eğitmendir ve insanları gizleri anlayabilecek hale getirerek Tanrı'nın ișini tamamlar ve kusursuzlaştırır."(Eliade, 1992: 115). Türklerin hayatına dair zengin bilgiler içeren Ergenekon destanı, bu özelliğiyle dönemin siyasi olayları hakkında bilgi verir. Demir madenini eriterek Ergenekon'dan çıkışları Türklerin demircilik mesleğinde ne derece ileri olduklarını gösterir. Göktürklerin Ergenekon'dan çıkmaları bir bayram olarak kabul edilmiştir. Türkler her yıl "Ecdat Mağarası"na giderek burada Göktürk kağanları ile törenlerde ataları için kurban keserlerdi (Dıngll, 2012: 157). Türk dilinin en temel dil kaynaklarından olan 
"Dîvânu Lugâti't-Türk"te "temür" kelimesi "demir"i ifade etmekte ve "Demirci" de "temürçi” olarak verilmektedir. Demir ile ilgili "Kök temür kerü turmas (Mavi demir-kılıç zarar vermeden hareketini bitirmez.)" atasözü bir çeşit yemin ve söz vermeyi ifade etmektedir. $\mathrm{Bu}$ atasözü; Kırgızlar, Yabagular, Kıpçaklar ve diğerleri biriyle ittifak yaptıklarında ya da yapılan bir anlaşmaya taraf olduklarında ant sembolü olan demiri ululamak için sıyrılmış kılıcı çıkararak yanlamasına önlerine koyup "Bu Gök girsin kızıl çıksın” deyişi bir yemini ifade eder. Bu "Anlaşmayı bozarsam bu mavi demir girsin, kızıl-kanlı çıksın" demektir. Bu büyük kudrete sahip olduğuna inandıkları demir kılıç tarafından sözünde durmayanın katledileceğine işarettir ve demiri kutsal sayan Türkler için bu ifade "sözünde durmazsam kılıç kanıma bulansın, demir öcünü alsın” demektir (Çerikan, 2014: 213).

\section{Türklerde Demir Üretimi}

İlk demir üretim ocakları kil, ocak taşı veya kopmuş kaya parçalarından yapılmış derin olmayan ilkel kuyu veya şaft fırınlarıdır. İlk zamanlar demir üretiminde odun kömürünü yakacak havayı sağlamak için rüzgâra açık, sarp alanlarda demir eritme fırınlarını kurulmuş ve fırınlar doğal hava cereyanları ile çalıştırılmıştır. Bu firınlarda odun kömürü ile temiz demir cevherleri karıştırılıyor, işlem sırasında cevhere yapışmış gang eriyip cüruf hâline gelirken dövülebilir demir katı hâlde indirgeniyordu. Demirin fırınlarda eritilebilmesi için gerekli sıcaklığa erişmek ancak yeterli miktarda hava takviyesi ile gerçekleşeceğinden yeterince hava sağlanması için elle veya ayakla çalıştırılan körük âleti keşfedilmiş ve kullanılmıştır. Körükler, deri tulumların birleştirilerek iç hacminin büyütülmesi ile içine tek akışlı klepeden giren havanın körüklerin üzerine bastırılmak suretiyle körük içinde sıkıştırılarak havanın uygun çaptaki bir borudan ocaktaki kömürün üzerine sevk edilmesi ile havadaki oksijenin kömürün yanma hızını artırarak yüksek sıcaklık üretilmesi esası üzerine çalışan basit bir emme-basma kompresörlerdir. Körüklerin gelişimini inceleyen araştırmacılara göre, ilk örnekleri deri körüklerdir, bu körüklerin hayvan derilerinin(genelde keçi derilerinin) birbirilerine dikilmesi ve çeşitli işlemlerden geçirilmesi suretiyle yapıldığı bilinmektedir. Deri körüklerin kökeni Türkistan'a dayanmaktadır ve deri körükler Türkistan'dan Yakın Doğu'ya, Avrupa ve Afrika'ya yayılmıştır. Türklerde demirciliğin yanında en önemli ekonomik uğraşın hayvancılık(özellikle koyun-keçi gibi küçükbaş hayvancılığı) olduğu dikkate alındığında körüklerin ilk örneklerinin deri körükler olması ve körüklerin kökeninin Türkistan'a dayanması, Türklerin demirciliği ile ilgili bilgileri destekleyen belgedir. Türk Kültürünün en önemli kaynaklarından Dîvânu Lugâti'tTürk(Kaşgarlı Mahmud) adlı eserde kuyumcu, demirci körüğü anlatılmakta ve "ateşi körüklemek" deyimi verilmektedir. Körük kelimesi Türk dünyasında halen yaygın kullanılan, yaşayan kelimedir ve demirci körügünü hatırlatmaktadır. Kırgızlarda "köörük" demirci körügünün karşılığı olarak geçmekte, Kuman-Kıpçaklar da bu âleti "kürük"olarak ifade etmektedirler (Yağcl, 2015: 29). Türk demircisinin demircilik sanatındaki yeterliliğinin göstergelerinden birisi de metal üzenginin tasarımı ve üretimidir. Üzenginin Doğu'da milattan önce en erken 4. yüzyılda Türklerin atası olarak kabul edilen İskitler tarafından bulunduğu ve kullanıldığı belirtilmektedir. Bu döneme ait bir İskit vazosu üzerindeki kabartmalar üzengi ile donatılmış eyeri göstermekte olduğundan, İskitlerin üzengiyi kullandıklarını gösteren bir kanıt olarak kabul edilmektedir. Birçok tarihçiye göre üzengi, insanlık tarihini değiştiren çok önemli bir icat olup üzengi sayesinde uzun süre ata binebilmek, uzun mesafeler kat edebilmek mümkün olmuştur. Bazı kaynaklarda üzenginin M.S. 4.-5. 
yy'de ilk olarak Çin'de kullanıldığı öne sürülmektedir. Türkolog Peter Golden üzenginin ilk defa Göktürkler tarafından icat edildiğini ileri sürmekte, Macar Türkolog, Rona-Tas ise yaptığı arkeolojik ve dilsel çalışmalara göre metal üzengiler için Göktürkler 'den daha önce icat edilmiş olamaz" ifadesini kullanmaktadır. Bu tanımlamalar üzenginin bir Türk buluşu olduğunu kesinleştirmektedir. Türkler, Çinlilerle yaptıkları savaşlarda üzengiye dayanarak başarı kazanmışlardır ve çok defa savaşta geri çekilirken, üzengi sayesinde Çinlileri ok yağmuruna tutabilmişlerdir. Eski Türklerin göçebe hayatı sürdürdüklerinden "at" hayatlarında birinci derecede önemli bir yer almıştır ve üzengi, eğer ve yular gibi kavramlar da açık olarak Türklerin buluşu olduğuna tanıklık etmektedir. Üzengi hem uzun mesafeli savaşların ve hem de insanoğlunun at sırtında seyahat ederek kültürel alışverişte bulunmasının önünü açan bir araç olarak tanımlanmaktadır (Çifci, 2020). Türk töresinde kutsal olan örs, çekiç, kıskaç ve işlenen kızgın demir Türk milleti için var olma mücadelesinin temel sembolleridir. Türklerde; at, avrat, silah deyimi içinde yer alan silahın temel malzemesi olan ve çekiç seslerinin ahenginde eriyen demirin (çelik) aldığı şekil yani kılıç, askeri birlik ve beraberliği temsil eden kutsal silahtır. Çekiç demircilikte kullanılan önemli bir âlettir ve Türkler çekice "çekük" adını vermişlerdi. Demire vurulan her çekiç darbesi onun yapısını daha da sıkılaştırıp sağlamlaştırırken aynı zamanda çekiç demire şekil vermek amacıyla kullanılmaktadır. Demir dövme işlemi yapılırken kullanılan önemli âletlerden biri de "örs"tür. Kızgın demiri örsün üstüne koyarak çekiçle dövme geleneği bugün de Türk devletlerinde temsilî Nevruz Bayramı olarak gerçekleştirilmeye devam etmekte ve ata yurduna dönüşün sembolü olarak tarihî bir olayın genç kuşaklara iletilmesini sağlamaktadır.

\section{Günümüzde Anadolu'da Demircilik}

Anadolu'da Demirciler Çarşısı denince; ortasında ateş yanan bir ocak, yanan ateşe can veren derin nefesli körük ve koca bir örsün yer aldığı, Türk el sanatlarının en kutsal kolu demirci dükkânı ve elbette sıcak demircilik sanatı hatırlanmaktadır. Günümüzden yarım asır öncesinde, demirci dükkânları genellikle eski kentlerin merkezlerinde yer alır ve kuruldukları dönemlerde bir anlamda o şehir için temel ağır sanayi tesisi kabul edilirdi. Demirci dükkânı ile değişim ve gelişim başlar, demircilerin yeni komşuları kalaycılar, tenekeciler, sobacılar, anahtarcılar, kilitçiler, onları takiben tornacılar ve giderek otomotiv sektörünün gelişmesiyle birlikte kaportacılar, motorcular, demirci çarşılarının demirbaşları olarak yerlerini alırlardı. Kırsal kesimlere açılan yolların başında yer alan kentlerde, demirci ocaklarında gündelik işler olarak balta, kazma, orak, çapa, kazmalı balta, pala, bıçkı bıçağı, ekmek bıçağı gibi aletler büyük bir dikkatle üretilirdi. Anadolu şehirlerinde hayat, demirci dükkânında yani Demirciler Çarşısı'ndan başlardı. Metalle uğraşan el sanatları da demircilere dâhil olmuş olmasına rağmen, pusat yapan kutsal kişi olduğundan sıcak demirci diğerlerinden farklı bir saygınlık görürdü. Bugün ülkemizin değişik yöre ve illerindeki birçok demirci esnafı, kırsal bölgelerde yaşayan insanların hayatlarını kolaylaştıracak demir-çelik malzemeden yapılmış kazma, balta, çapa, bel, çivi, burgu demiri, keski, burç vb. gibi ürünleri üretmektedirler. Demirciler Çarşısı esnafının diğer el yapımı ürünleri; kapı kilidi, kapı göbeği, kapı tokmağı, kabara çivisi, menteşe, kapı ve pencere demiri, tırpan, orak, hayvan çanı, bıçkı bıçağı, bel, kürek, çapa, tırmık, at gemi, at nalı, üzengi, dizlik gibi önceki yüzyılların gözde ürünleri sıralanabilir. Anadolu'da eski günlerdeki gibi canlı olmasa da hayatın nabzı hala demirci dükkânlarında atmakta ve bu özellik birçok şehirde 
hâlâ varlığını korumaktadır. Mardin'in Demirciler Çarşısı olan Cumhuriyet Çarşısı yüzyılların birikimi ile bugünü 1102-1409 arasında 300 yıl hüküm sürmüş Oğuz Türkmen Beyliği Artukoğulları dönemine götürmektedir. Mardin Çarşısı'ndaki demirci dükkânının bacası artık eski yıllarda olduğu gibi her gün tütememekte, fakat çarşıdaki demirci esnafının meslek büyüğü olarak hürmet görmüş uluları dilden dile yad edilmektedir. Artuklu Beyliği'nin tarihe veda ettiği 1400'lü yıllarından bu yana tarihi çarşıda 600 yıldır Artukoğlu'nun demirci dükkânında körüklü bir ocak yanmaya ve örsün üzerindeki kızgın demir üzerine çekiç vurmaya devam etmektedir. Eski adı Yoğurt Pazarı olan çarşının uzağından duyulmaya başlayan örs üzerinde patlayan çekiç sesleri ile ünlenmiş Tarihi Diyarbakır Demirciler Çarşısı da bugün geçmişe özlem duymaktadır. Bugün Demirciler Çarşısı'nın giderek azalan sıcak demircileri olumsuzluklara direnerek, geleneğin izinden yürümeye devam etmekte ve demircilik el sanatını sürdürmeye çalışmaktadırlar. Şekil 1 de Örs, çekiç, kıskaç ve sıcak demir görülmektedir.

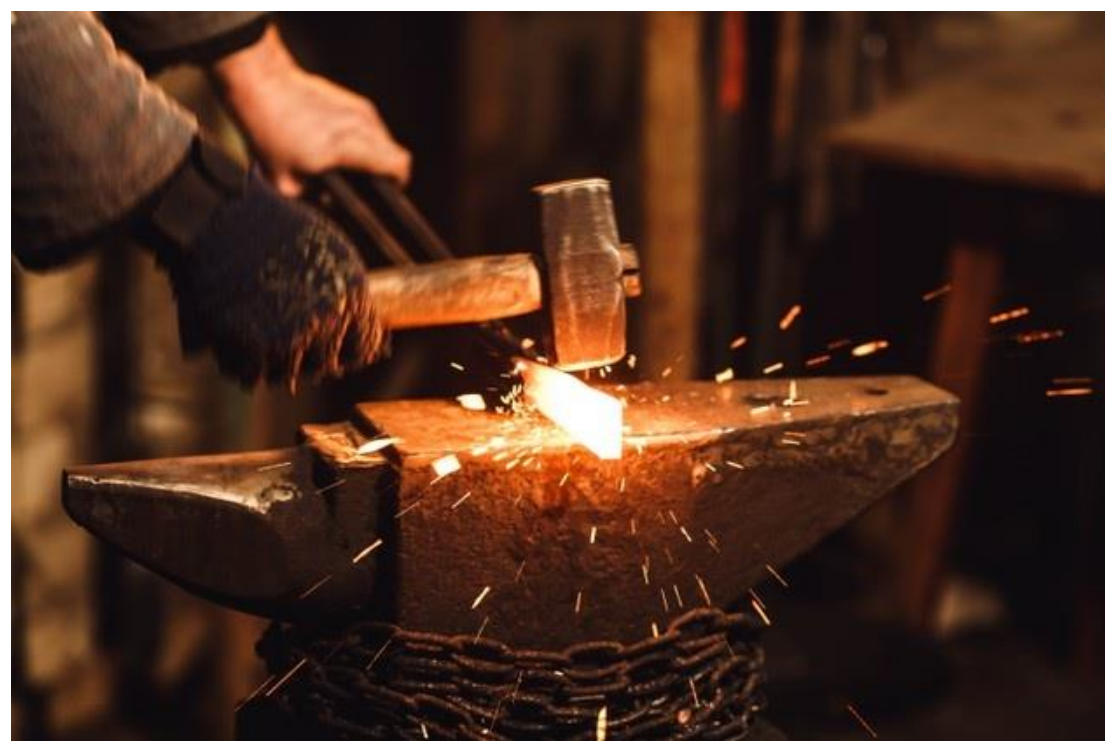

Resim 1 Örs, Çekiç, Kıskaç ve Sıcak Demir

Demircilikte, usta-çırak saygısının yıllar geçse de yitmediği ve el sanatlarının temelinde bulunan "usta-çırak" ilişkisinin her dönem belirleyici olduğu bilinmektedir. Bir zamanlar, Demirciler Çarşısı'nda her usta garanti anlamı taşıyan kendi özel işaretini ürettiği ürünlerine damga olarak işler, köylü elinde ucu kırılmış bir aletle çarşıya geldiğinde üzerindeki işarete bakılarak hangi ustanın elinden çıkmış olduğu hemen belirlenirdi. Köylü, kırık aletle birlikte o dükkânda ustaya damgasını gösterir, usta kendi malını tanıyıp geri alır, eğer onarılacak gibiyse onarıp iade eder veya tamir edilemeyecek durumda ise yenisinden bir tane takdim ederdi. Para almadan yapılan bu yenileme işlemi ile yüzyıllardan beri bu geleneğin Demirciler Çarşısında yakın zamana kadar sürdürüldüğü anlatılmaktadır. Safranbolu Demirciler Çarşısında ise, öncelikle çarşının mimari güzelliği ve Safranbolu evlerinin kapılarının ahşap ve demir işçiliği öne çıkmaktadır. Osmanlı belgelerine göre 1560'lı yıllarda Safranbolu'da demircilik temel mesleklerin başında yer almaktadır. Safranbolu'da 3. Selim'in sadrazamlarından İzzet Mehmet Paşa tarafından 1796'da yaptırılan tarihi Demirciler Çarşısı günümüzde UNESCO Dünya Mirası listesinde yer almaktadır. 224 yıl önce kurulduğunda 40 demirci dükkânının yer aldığı, 1924 yılında 105 dükkânı 
olan Demirciler Çarşısı'nda ne yazık ki bugün ustalar mesleği sürdürecek eleman bulmakta sıkıntı yaşamaktadırlar. Dünyaca ünlü Safranbolu konakları başta olmak üzere kırsaldaki geleneksel evlerin kapı tokmakları, kilitleri ve demir süslemelerinin yanı sıra, son yıllarda Türk tarihini anlatan filmler ve televizyon dizilerinde kullanılan kılıç, kalkan, miğfer gibi değişik malzemeleri de yapan ustalar, teknolojiye karşı mücadele vermeye ve direnmeye çalışmaktadır. 0 yıllarda Safranbolu Demirciler Çarşısı'nda hangi ürünler yapılıyorsa bugün de eşleri, benzerleri, gelişmiş modelleri üretiyor ve geniş sokağın ortasında "Demirciler Loncası" eski dönemin anıtı olarak Safranbolu Demirciler Çarşısı'nın zamana karşı hala mekân olarak direndiğini gösteriyor.

Çelikleri kızgın atește ısıtıp örs üzerinde döverek ürüne dönüştüren el sanatlarının en kutsalı demircilik mesleği de teknolojinin gelişimi ile Anadolu'da, yavaş yavaş tükenmektedir. Türk kültüründe yeni ölmüş birinin üzerine bıçak, kılıç, makas gibi demir aletler bırakılması, insan adı, soyadı, belde ve köy adını demirciler, demirci vb. isimler verilmesi demirin ve demirciliğin Türklerdeki önemini göstermektedir. Manisa'nın mesleğin adını taşıyan Demirci ilçesinde yaklaşık 60 yıldır demircilik yapan son ustası mesleğin son temsilcisi olarak işini sürdürüyor. Denizli'nin tarihi Kaleiçi Çarşısı içerisinde sayıları giderek azalan demircilik mesleğinde çırak yetişmediği için dükkânlar yavaş yavaş kapanmaya başlamıştır. Antalya'nın Akseki ilçesine yaşayan 84 yaşındaki demirci ustası, dedesinin başlattığı sıcak demirciliği babasından devralarak 68 yıldır sürdürmekte ve bir zamanların en önemli mesleklerinden sıcak demirciliğin eskisi kadar ilgi görmediğini ifade etmektedir. Günümüzde eskisi kadar rağbet görmese de Erzincan şehir merkezinde ve Kemaliye ilçesinde varlığını sürdüren demircilik sanatının önemli ürünlerinden biri olan el yapımı kapı tokmakları halen üretilmekte ve şimdilik ilgi görmeye devam etmektedir. Trabzon'da demircilik mesleğinin yok olduğunu ifade eden demirci ustaları, ülke genelinde şehirleşmenin artmasıyla tarım alanlarını azaldığını, artık kimsenin tarlaya gitmediğini buna bağlı olarak da tarımda kullanılan demir aletleri üreten demircilerin mesleğinin de bitme noktasına geldiğini ifade etmektedirler. Teknolojiye yenik düşen mesleklerden biri olan sıcak demirciliği, Malatya'da yıllardır sürdüren demirci ustası özellikle son dönemlerde tarihi diziler ile kılıçlara gösterilen ilginin arttığını, teknolojiye yenik düşen mesleklerin başında geleneksel demirciliğin geldiğini ve tek üzüntüsü ise kendisinden sonra mesleği bırakacağı birinin olmadığını söylemektedir. Sungurlulu demirci ustası, Türk el sanatları içinde 'demircilik' önemli bir yer tutmakta olduğunu, fakat artık şehirlerde sayıları birkaç kişiyi geçmeyen demircilikte çırak yetişmediği için mesleğin yakın zamanda hiç icra edilmeyeceğini ifade etmektedir. Eskiden Bitlis'te yoğun şekilde yapılan demircilik zaman içinde gittikçe azalmış, günümüzde ise il merkezinde birkaç usta tarafından devam ettirilir duruma gelmiştir. Kurtuluş Savaşında, 42. ve 47. gönüllü alaylarında Karadeniz yapısı eğri bıçakları ile düşman üzerine atılan Giresun Uşaklarının demircilik mesleğindeki son temsilcileri de mesleğe veda etmektedirler. Dedesi Giresun Uşaklarından olan Eynesil'in son demirci ahisi Ali Usta 62 yıl çalıştıktan sonra 84 yaşında demirci körüğünü söndürmüş, örsünü, körügü̈nü ve kalan aletlerinden evinin bodrumunda bir müze yaparak mesleğini yaşatmaya devam edeceğini ifade etmiştir. Giresun'un Görele ilçesinde yaşayan 'Demirci Mustafa Hoca', Camide imamlık yaptığı yıllarda boş zamanlarında demirci dükkânında babasına yardım ederek mesleği öğrendiğini, babasının vefatından sonra imamlıktan emekli olup demirciliğe başladığını, 72 yaşında olduğunu ve gücünün yettiği kadar çalışmaya devam edeceğini belirtmiştir. Resim 2 de müzede sergilenen emekli bir çekiç görülmektedir. 


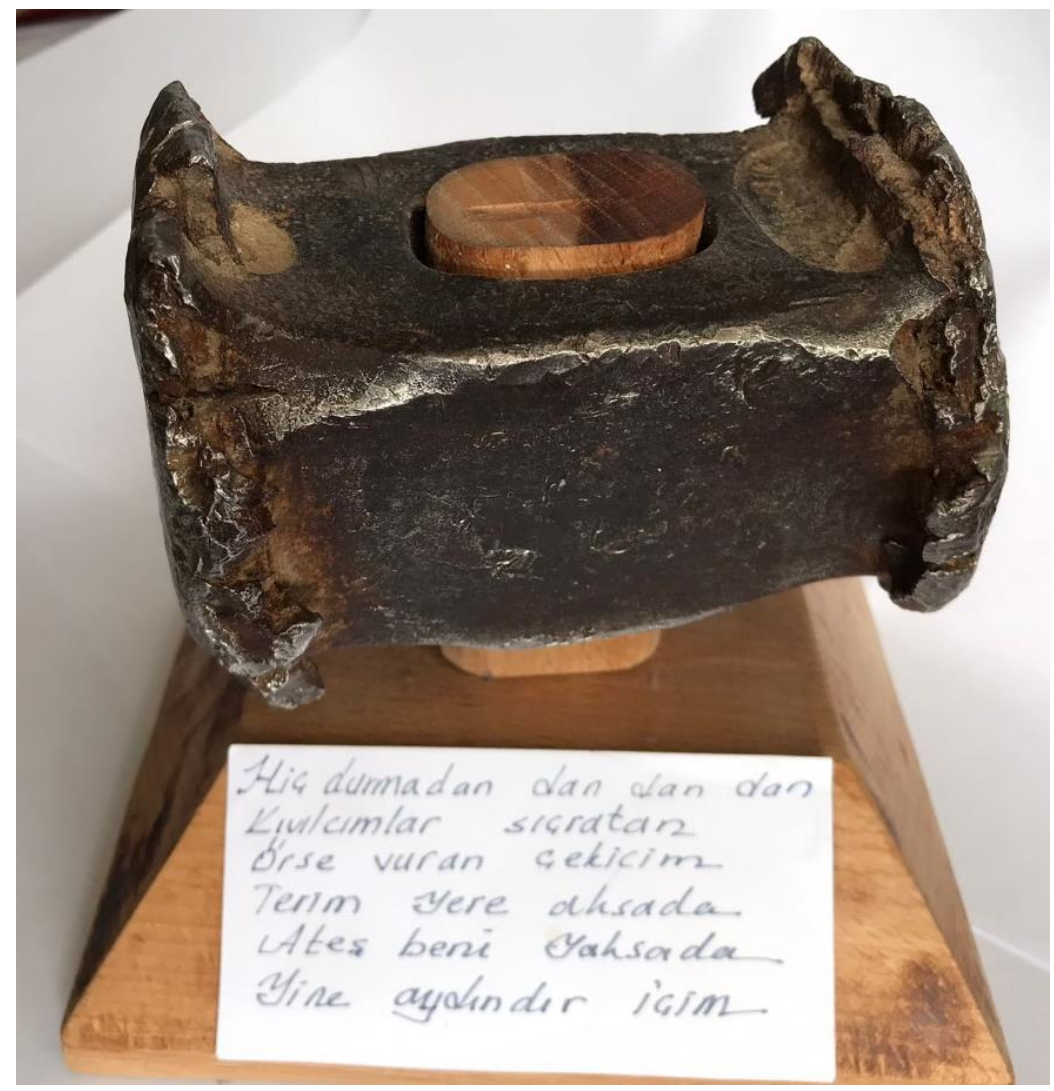

Resim 2 Müzede sergilenen emekli bir çekiç

Türk toplumunda asırlardan bu yana en güzide meslek dallarından biri olan demircilik, yaşanan teknolojik gelişmelerle birlikte rekabet edemediğinden gücünü kaybetmiş, unutulmaya ve kaybolan meslekler içinde yer almaya başlamıştır. Demircilikte faaliyet gösteren ustaların birçoğu çırak yetiştiremeden hayatını kaybederken, bir kısım demirci esnafı da endüstriyel değişim ve gelișimle birlikte sektör değiștirmek zorunda kalmıștır. Geçmişte, Anadolu'nun her şehrinde her köşe başında olan demirci atölyeleri, son yıllarda "demirci mesleğinin geleceğinde işık yok, istikbal yok düşüncesi" ile hızla azalmaktadır. 2000'li yıllara kadar yoğun şekilde çalışan ve iş üretme fırsatı bulan demirciler 2000'li yıllardan sonra e-ticareti de içine alan teknolojik etki ile rekabet edemediğinden veya talep olmadığından artık üretemez durumdadırlar. Bugün, illerimizde bir elin parmaklarını geçmeyecek sayıda kalan demirci ustaları da günlük çok cüzi kazançlarla hayatlarını idame etmeye çalışmaktadır.

\section{Sonuç}

Tarihinin başlangıcından günümüze demircilik mesleği daha ziyade sıcak demirciliği temel alarak varlığını sürdürülmüştür. Günümüzde tarım merkezli sıcak demirciliğin yerine teknolojik araçların kullanılmasının sonucunda seri üretim teknikleri soğuk demirciliğin gelişmesini sağlamıştır. Bu sürecin sonucunda sıcak demircilik yapan küçük demirci atölyeleri olumsuz etkilenerek bir değişim geçirmektedir. Bugün Anadolu'da tarım ve hayvancılık bir sektör olarak varlığını koruduğu sürede ve ölçüde çarşının demircileri bu sektör özel ürünler üretmeye devam edeceklerdir. Bu çarşılar tarihi dokusundan dolayı bir 
sanat galerisi özelliği taşımasına rağmen daha ziyade bölgenin ekonomik yapılanmasına göre oluşan, gelişen veya tasfiye olan ticari işletmelerdir. Kırsalda yaşayan, tarım ve hayvancılık işini yaparak yaşayan çevre insanının hayatındaki sosyal değişim, ekonomik değişkenler ve politikalar çarşıları da doğrudan etkilemektedir.

Günümüzde yöresel özellikleri de içeren ve geleneksel olarak nitelenen ürünlerin işlevlerinde yaşanan önemli dönüşüm sıcak demircilik mesleğinin kendisine yeni alanlar araması üzerinde etkili olmuştur. Bilindiği gibi sıcak demircilerin aynı zamanda pusat ustaları olması demircilerin bu özelliğini ön plana çıkarmış ve yenilenen demirci mesleğinin bıçak yapım sektörüne ilgisini artırmıştır. Son yıllarda özellikle televizyon kanallarında yoğun olarak yer alan tarihi diziler sıcak demircilik sektöründe eski silahlara olan ilgiyi artırmıştır. Bu ilgi, tarihi ve kültürel el sanatları ürünlerinin günümüz popüler kültür ve turizm alanında önemli bir pazar alanı bulacağını göstermektedir. Sıcak demirci ustaları atölyelerinde, bu pazara dönük alternatif ürünler ile turizm sektörünü için iş üretebilirler.

Demirin tarihi ve kültürel el işi ürüne dönüştürülerek, geleneğin sıcak demirci ustalarının geleceğin ustalarına dönüşümünü sağlayacak fırsatları yakalayabilecek aktivitelerin geliştirilerek sıcak demirci geleneğinin korunmasına ve sürdürülebilirliğine katkı yapılabilir. Bugün e-ticaret üzerinden bu tür ürünler sanal pazar ortamında büyüyen bir pazar payına sahip olmaya başlamıştır.

Örs, çekiç, kıskaç, körük ve kızgın demir, Türk milletinin dünden bugüne var olma mücadelesinin temel taşlarıdır. Anadolu'nun herhangi bir ilinde, ilçesinde veya beldesinde bir Anadolu insanı çarşıya uzaktan yaklaşırken örs ve çekiç seslerini duyduğunda, Ergenekon yaylasında başlayan destanın belki de son örs sesini duymanın mutluluğunu yaşayacaktır. Her Ergenekon Bayramı kutlaması özgürlügün elden çıkmasına ve tutsaklığa sebep olan hatalar olarak hafızalarda yer alırken, demircinin her çekiç vuruşunda tarih yeniden hatırlanacaktır.

Gelecek nesillere bu değerlerin taşınması ve sürdürülebilirliği için "İl gider, Töre kalır" deyimi başta sıcak demircilik olmak üzere kaybolan mesleklerin genç kuşaklara aktarılması gerekmektedir. Bunun için özellikle yerel yönetimlerce "Somut Kültürel Miras Taşıyıcı Meslekler ve Çocuk Müzeleri” ismi altında atölyeler yapılarak bu mesleklerin tanıtılmasının alt yapısı kurulmalıdır. Bu "Somut Kültürel Miras Taşıyıcı Meslekler ve Çocuk Müzeleri” hem geleneklerin yaşatılmasını ve hem de genç kuşakların bilgi, birikim ve yeteneklerinin gelişmesini sağlayacak farkındalıklar üretecektir.

\section{Kaynakça}

Bastem, N.(2019). Türeyiş Destanıyla İlgili Tüm Rivayetlerin Karşılaştırılması ve Kültürel Kodlar Üzerine Bir İnceleme. Atatürk Üniversitesi Türkiyat Araştırmaları Enstitüsü Dergisi, Erzurum, 66, 225-236.

Çifci, E. (2011). Savaşları Değiștiren 50 Silah At ve Üzengi, http://dunyaharptarihi.com.

Dıngll, F. A. (2012). Íslam Öncesi Türk Kültüründe Kutsallık İzafe Edilen Maddi Unsurlar. Yüksek Lisans Tezi, T.C. İstanbul Üniversitesi Sosyal Bilimler Enstitüsü, İstanbul. 
Durmuş, İ.(2017). Bozkır Kültür Çevresinde At, Göçer-Ev ve Demir. Asya Araştırmaları Dergisi, 1(1), 19-34.

Eliade, M. (1992). Imgeler Simgeler (Çev.Ç M. Ali Kılıçbay). Ankara: Gece Yayınları.

Gömeç, S. (2009). Türk Destanlarına Giriş. Ankara: Akçağ Yayınları.

İnan, A. (1986). Tarihte ve Bugün Şamanizm. Ankara: Türk Tarih Kurumu.

Kafesoğlu, İ. (1977). Türk Millî Kültürü. İstanbul: Ötüken Neşriyat.

Koçak, K. (2016). Bozkır Türk Kültüründe Demirin Ortaya Çıkışı ve İşlenip Yayılması. Turkish Studies, 11(1), 77-88.

Ögel, B. (1991). Türk Mitolojisi (Kaynakları ve açıklamaları ile destanlar), I. Cilt (Tıpkıbasim) Ankara: Türk Tarih Kurumu.

Taşağıl, A. (2003). Göktürkler. Ankara: Türk Tarih Kurumu.

Uğur Çerikan, F. (2014). Türk Kültüründe Demir. Doktora Tezi, Pamukkale Üniversitesi Sosyal Bilimler Enstitüsü, Denizli.

Yağcı, M. (2015). Türk Kültüründe Demir ve Demircilik (VI-XII. Yüzyıllar). Yüksek Lisans Tezi, Afyon Kocatepe Üniversitesi Sosyal Bilimler Enstitüsü, Afyonkarahisar.

Ziya Gökalp. (1991). Türk Uygarlık Tarihi. İstanbul: İnkılap Kitabevi. 